\title{
Increased matrix metalloproteinase-9 in male elderly with low 25-hydroxy-vitamin D
}

\author{
Pusparini*, Lie Tanu Merijanti**, and Novia I. Sudharma***
}

\section{ABSTRACT}

\section{BACKGROUND}

One of the extra-skeletal roles of vitamin D for health is associated with cardiovascular disease. Poor vitamin D status has been associated with vascular endothelial dysfunction. There were controversial results about the association between vitamin D deficiency and matrix metalloproteinase 9 (MMP-9) concentration. The purpose of the present study was to determine the concentrations of $25(\mathrm{OH})$ vitamin $\mathrm{D}$ [25(OH)D] in an elderly population and to find any association between $25(\mathrm{OH}) \mathrm{D}$ and MMP-9 concentrations.

\section{METHODS}

This study was of cross-sectional design involving 160 male and female subjects aged 55-65 years, in South Jakarta, Indonesia. Determination of MMP-9 and 25(OH)D concentrations was done concurrently on subjects who met the inclusion and exclusion criteria after all study subjects had been selected. 25(OH)D and MMP-9 concentrations were assessed by direct competitive chemiluminescence immunoassay (CLIA) and enzymelinked immunosorbent assay (ELISA) respectively. Statistical analysis used chi square and t tests.

\section{RESULTS}

Mean 25(OH)D concentration in the study subjects was $14.4 \pm 6.4 \mathrm{ng}$ / $\mathrm{mL}$. A total of $68.8 \%$ of subjects had a $25(\mathrm{OH}) \mathrm{D}$ level of $<20 \mathrm{ng} / \mathrm{mL}$, and $31.2 \%$ had a $25(\mathrm{OH}) \mathrm{D}$ level of $>20 \mathrm{ng} / \mathrm{mL}$. There was an increased MMP9 concentration in male subjects with a $25(\mathrm{OH}) \mathrm{D}$ level of $<20 \mathrm{ng} / \mathrm{mL}$ compared with subjects with $25(\mathrm{OH}) \mathrm{D}$ level of $>20 \mathrm{ng} / \mathrm{mL}(\mathrm{p}=0.011)$, but not among female subjects $(\mathrm{p}=0.809)$.

\section{CONCLUSION}

The MMP-9 concentration was increased among male subjects with low level of $(\mathrm{OH}) \mathrm{D}$. This study confirmed that $25(\mathrm{OH}) \mathrm{D}$ concentration may have a potential role in endothelial function.

Keywords: Endothelial function, MMP-9, 25(OH)D, vitamin D deficient, elderly
*Department of Clinical Pathology, Faculty of Medicine,

Trisakti University, Jakarta,Indonesia **Department of Occupational Medicine, Faculty of Medicine, Trisakti University, Jakarta, Indonesia

***Department of Community Medicine, Faculty of Medicine, Trisakti University, Jakarta, Indonesia

\section{Correspondence:}

Dr. dr. Pusparini, SpPK

Department of Clinical Pathology,

Faculty of Medicine,

Trisakti University

Jl. Kyai Tapa no 260, Grogol, Jakarta 11440, Indonesia.

Phone: +62-21-5655786,

Fax: +62-21-5660706

Email: pusparini_sppk@yahoo.com

Univ Med 2016;35:171-80

DOI: 10.18051/UnivMed.2016.v35.171-180 pISSN: 1907-3062 / eISSN: 2407-2230

This open access article is distributed under a Creative Commons Attribution-Non Commercial-Share Alike 4.0 International License 


\section{INTRODUCTION}

Vitamin D deficiency is a health problem commonly found worldwide. Vitamin D deficiency is found in around one-third to one-half of the population, from young adults to elderly. Approximately $50 \%$ and $60 \%$ of elderly in North America and the rest of the world, respectively, do not have satisfactory vitamin D levels. ${ }^{(1)}$ Vitamin D concentrations are influenced by seasonal change, dietary intake, and clothing customs. Lack of vitamin D is caused by inadequate exposure to sunlight and by dietary intakes low in vitamin D. Vitamin D deficiency is most frequently associated with musculoskeletal disorders. In addition, vitamin D deficiency is also a risk factor for hypertension, various types of cancer, autoimmune diseases, type 2 diabetes mellitus, and cardiovascular diseases. ${ }^{(2-4)}$ Ecological studies have shown that coronary heart disease and hypertension are frequently found in regions far from the equator, with relatively low exposure to sunlight. ${ }^{(5,6)}$

Vitamin D receptors are widely distributed in the body, e.g. in vascular smooth muscle, vascular endothelium, and in cardiomyocytes. In vitro studies show that activation of 1,25 hydroxyvitamin $\mathrm{D}(1,25 \mathrm{OH} \mathrm{D})$ directly inhibits renin gene expression and regulates the growth and proliferation of vascular smooth muscle cells and cardiomyocytes. Studies in knockout rats prove that lack of activation of vitamin D receptors causes disorders of the renin-angiotensin system, leading to hypertension and left ventricular hypertrophy. ${ }^{(1,7)}$

In the elderly, the prevalence of cardiovascular diseases increases exponentially with advancing age. The elderly have increased total cholesterol, low density lipoprotein cholesterol, and triglyceride concentrations, but slightly reduced high density lipoprotein cholesterol concentrations. In addition, there are changes in glucose metabolism, such that glucose concentrations tend to increase and insulin sensitivity to decrease. Other changes are in the activation of coagulation with increasing fibrinogen and plasminogen activator inhibitor (PAI-1) concentrations. In the elderly there occurs a process called endothelial dysfunction, with markers such as von Willebrand factor (vWF), endothelial leukocyte adhesion molecule-1 (ELAM-1), intercellular cell adhesion molecule1 (ICAM-1), vascular cell adhesion molecule-1 (VCAM-1) and matrix metalloproteinase-9 (MMP-9). ${ }^{(8,9)}$ MMP-9 is one of the matrix metalloproteinases, a group of zinc-dependent extracellular enzymes, and plays a major role in the degradation of the extracellular matrix involving tissue remodelling. MMP-9 is also called gelatinase and has a molecular weight of $92 \mathrm{kDa}$. The MMP-9 levels are increased in several cardiovascular diseases, including hypertension, atherosclerosis and myocardial infarction. ${ }^{(10-13)}$

Several studies have reported on the association between vitamin D deficiency and MMP-9 concentration. The study by Timm set al. ${ }^{(14)}$ reported that vitamin D insufficiency is associated with increased circulating MMP-2, MMP-9 and C reactive protein (CRP), correctable by supplementation of cholecalciferol. The study of Wasse et al. ${ }^{(13)}$ reported the finding of a significant inverse correlation between $25(\mathrm{OH}) \mathrm{D}$ concentration and MMP-9 concentration in patients with terminal renal failure. Another study by Shab-Bidar et al. ${ }^{(15)}$ reported that regular consumption of vitamin D-fortified yogurt drink (doogh) for 12 weeks resulted in a significant improvement in endothelin-1, endothelial selectin and MMP-9 in subjects with type 2 diabetes. The study of Baker et al. ${ }^{(16)}$ showed a significant inverse correlation between MMP-9 and vitamin $\mathrm{D}$ levels $(\mathrm{r}=-0.41 ; \mathrm{p}=0.01)$. The study of Lucey et al. ${ }^{(17)}$ which was a randomized double blind placebo controlled trial, showed no effects of vitamin D supplementation on MMP-9 concentrations. The aim of the present study was to determine the $25(\mathrm{OH}) \mathrm{D}$ concentrations in the elderly and to find any association between 25( $(\mathrm{OH}) \mathrm{D}$ concentrations and MMP-9 concentrations in the elderly. 


\section{METHODS}

\section{Study design}

This cross-sectional study was conducted from April 2013 until June 2013 at Mampang Prapatan district, South Jakarta, Indonesia.

\section{Study subjects}

The study population used in this study comprised elderly residents of Mampang Prapatan district, South Jakarta, aged 55-65 years and selected by simple random sampling. Inclusion criteria in this study were: elderly persons aged 55-65 years, agreeing to participate in the study (by signed informed consent) after receiving explanations about the purpose of this study, ambulatory (capable of walking actively without walking aids), capable of verbal communication (capable of answering questions by themselves or aided by others). The exclusion criteria were: not being on corticosteroids, hormone replacement therapy, vitamin D supplements, not suffering from coronary heart disease, hypertension, diabetes mellitus, or stroke, ascertained from the history (anamnesis) of the subjects. To calculate the sample size, we used a previous study by Wasse et al. ${ }^{(13)}$ who reported the prevalence of low 25(OH)D was 0.43 . The calculated sample size was 182 , which was estimated using level of significance 0.05 and the precision 0.05 .

\section{Data collection}

The distributed questionnaires contained the following items: identity of respondent, health status, medical history, family history, history of habits, sports activities, sunlight exposure, clothing style, and use of sunblocking agents.

Study subjects who had been interviewed and met the inclusion and exclusion criteria by interview were asked to visit the health centre. The subjects were asked to fast overnight for 12 hours, previous to undergoing blood sample collection for routine laboratory tests. The following morning the subjects visited the health centre and underwent physical examinations, comprising blood sample collection and measurement of blood pressure using a mercury sphygmomanometer, pulse rate using a stopwatch, and body temperature. Determination of blood pressure, temperature and pulse rate was done by 2 trained nurses.

\section{Anthropometric measurements}

Height was measured in $\mathrm{cm}$ using a portable microtoise with a precision of $0.1 \mathrm{~cm}$, weight was measured in $\mathrm{kg}$ to the nearest $0.1 \mathrm{~kg}$ using Sage portable scales. Abdominal circumference was measured in $\mathrm{cm}$ to the nearest $0.1 \mathrm{~cm}$, using a measuring tape. Abdominal circumference was taken as the minimum circumference between the umbilicus and the xiphoid process and measured to the nearest $0.5 \mathrm{~cm}$. Body mass index (BMI) was calculated as the quotient of weight in $\mathrm{kg}$ and the square of height in $\mathrm{m}$. Determination of weight, height, and abdominal circumference was done by 2 trained nurses.

\section{Laboratory analysis}

Blood samples were collected after 10-12 hours of fasting and the laboratory tests were done on $5 \mathrm{~mL}$ venous blood samples. Sera were collected and stored until all subjects had finished and had been screened on fasting blood glucose to rule out diabetes mellitus. Determination of MMP-9 and 25(OH)D concentrations was done concurrently on subjects who met the inclusion and exclusion criteria after all study subjects had been selected. From the subjects who had fasted for 12 hours, $10 \mathrm{~mL}$ blood samples were collected for laboratory determination of $25(\mathrm{OH}) \mathrm{D}$ and MMP-9. The 25(OH)D concentrations were assessed by direct competitive chemiluminescence immunoassay (CLIA) using the Diasorin Liaison system and Diasorin reagents (integral catalog number: en 310600LIAISON 36290 8/11). Determination of MMP-9 concentrations was by enzyme-linked immunosorbent assay (ELISA) using R\&D system human MMP-9 reagents (Minneapolis, MN 55413, USA, catalog number: DMP 900, lot number 307038). 25(OH)D and MMP-9 concentrations were expressed in $\mathrm{ng} / \mathrm{mL}$. 


\section{Ethical clearance}

The study was performed after approval of the procedure by the Ethical Committee, Faculty of Medicine, Trisakti University, Jakarta, under registration number 51/KER/FK/05/2013. At recruitment specially trained field workers explained the study protocol to the study subjects before requesting their written informed consent.

\section{Statistical analysis}

Tests on the normality of the data distribution using the Kolmogorov-Smirnov test showed that the data were normally distributed. Subject characteristics were presented as mean and standard deviation. To evaluate factors affecting $25(\mathrm{OH}) \mathrm{D}$ concentrations in male and female subjects, the $t$ and chi square tests were used.

\section{RESULTS}

A total of 225 respondents aged 55-65 years who were willing to participate in this study after receiving explanations about the purpose of this study were enrolled. Among the 225 subjects who had filled in the study questionnaire, there were 52 who did not meet the criteria, among whom 17 subjects aged above 65 years, 7 subjects aged below 55 years, 2 subjects consuming antiplatelet agents such as aspirin, 2 subjects had suffered from stroke, 2 subjects were suffering from asthma, 6 subjects were suffering from heart disease, 2 subjects were suffering from goiter, 1 subject was suffering from liver disease and 13 subjects did not appear on the appointed days during the study, although they had expressed their willingness to participate in the study. There were 173 study respondents who came for physical and laboratory examinations and met the inclusion and exclusion criteria. Among them were found 13 respondents with diabetes mellitus according to fasting glucose measurements, yielding 160 subjects meeting the inclusion and exclusion criteria. The flowchart of subject participation is shown in Figure 1.

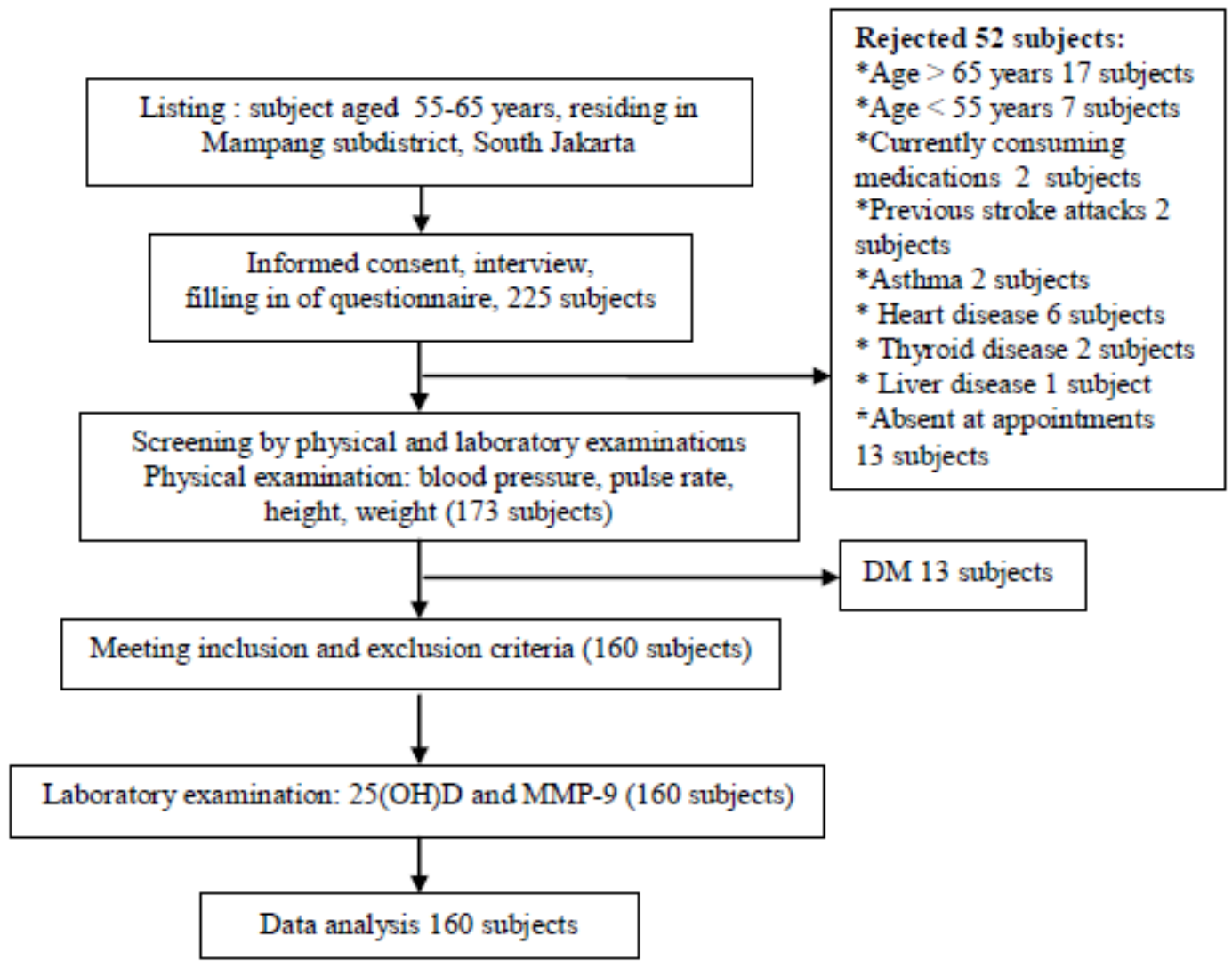

Figure 1. Flow of subject participation during study 
Table 1. Distribution of characteristics of study subjects $(\mathrm{n}=160)$

\begin{tabular}{|c|c|}
\hline Charac teristic & n (\%) \\
\hline Age(years) & $59.4 \pm 3.1$ \\
\hline \multicolumn{2}{|l|}{ Gender } \\
\hline Fern ale & $106(66.3)$ \\
\hline Male & $54(33.7)$ \\
\hline \multicolumn{2}{|l|}{ Education } \\
\hline No formal education & $8(5)$ \\
\hline Not finishing prim ary school & $23(14.4)$ \\
\hline Prim ary school & $55(34.3)$ \\
\hline Junia high school & $31(19.4)$ \\
\hline Senior high schoo & $40(25)$ \\
\hline Academy & $3(1.9)$ \\
\hline \multicolumn{2}{|l|}{ Employment status } \\
\hline Em ployed & $38(23.8)$ \\
\hline N ot employed & $122(76.2)$ \\
\hline \multicolumn{2}{|l|}{ Ethic group } \\
\hline Sundanese & $16(10)$ \\
\hline Javanese & $82(51.3)$ \\
\hline Betawi/Jak arta & $57(35.6)$ \\
\hline Other & $5(3.1)$ \\
\hline Abdaminal cir cumference (cm) & $88.8 \pm 11.5$ \\
\hline Hip circumference cm) & $95.1 \pm 8.6$ \\
\hline Weight ( $\mathrm{kg})$ & $59.9 \pm 11.2$ \\
\hline Height (cm) & $153.1 \pm 7.5$ \\
\hline Body $\mathrm{m}$ ass index $\left(\mathrm{kg} / \mathrm{m}^{2}\right)$ & $25.5 \pm 4.3$ \\
\hline$<25$ & $77(48.1)$ \\
\hline $25-29.9$ & $61(38.1)$ \\
\hline$\geq 30$ & $22(13.8)$ \\
\hline Systdic pressure ( $\mathrm{mmH}$ g) & $137.8 \pm 25.8$ \\
\hline Di astolic pressure (m mHg) & $83.9 \pm 12.9$ \\
\hline Pulse rate (per minute) & $78.2 \pm 9.5$ \\
\hline \multicolumn{2}{|l|}{ Lipid profile } \\
\hline Tdal chdesterol (mg/dL) & $201.6 \pm 36.5$ \\
\hline Triglycerides ( $\mathrm{mg} / \mathrm{dL})$ & $139.9 \pm 72.6$ \\
\hline HDL chde ster ol (m g/dL) & $48.9 \pm 8.7$ \\
\hline LDL cholester ol $(\mathrm{mg} / \mathrm{dL})$ & $134.9+33.6$ \\
\hline Fasting bl ood gucose $(\mathrm{mg} / \mathrm{dL})$ & $101.6 \pm 37.6$ \\
\hline MMP-9 (ngm L) & $789.8 \pm 414.7$ \\
\hline $25(\mathrm{OH}) \mathrm{D}(\mathrm{ng} / \mathrm{mL})$ & $14.4 \pm 6.4$ \\
\hline$\leq 20 \mathrm{ng} / \mathrm{mL})$ & $110(68.8)$ \\
\hline$>20 \mathrm{ng} / \mathrm{mL}$ & $50(31.2$ \\
\hline \multicolumn{2}{|l|}{ Nutrient intak e per day } \\
\hline Energy (kcal) & $1757.5 \pm 705.2$ \\
\hline Car bohydrate (g) & $276.6 \pm 103.8$ \\
\hline Protein (g) & $39.9 \pm 18.3$ \\
\hline $\mathrm{F}$ at (g) & $54.9 \pm 31.5$ \\
\hline Vitamin D (m g) & $6.6 \pm 2.4$ \\
\hline
\end{tabular}

*Mean \pm S.D.

Characteristics of the study subjects are presented in Table 1. The respondents participating in this study totalled 160 subjects, with a mean age of $59.4 \pm 3.1$ years. Most study subjects were females $(66.3 \%)$. With regard to
Table 2. Distribution of characteristics of subject activities associated with sunlight exposure

\begin{tabular}{lc}
\hline \multicolumn{1}{c}{ Characteristic of ac tivities } & $\mathbf{n ( \% )}$ \\
\hline Exposed to sunlight & $141(88.1)$ \\
$\quad$ Yes & $19(11.9)$ \\
No & $69(48.9)$ \\
Sunbathing period/day & $72(51.1)$ \\
$<15$ m inutes & \\
$\geq 15$ minutes & $72(51.1)$ \\
Sunbathing frequency/week & $69(48.9)$ \\
$<3$ tim es & \\
$\geq 3$ times & $128(90.7)$ \\
Sunbathing hours & $13(9.2)$ \\
$<9.00$ AM & \\
$\geq 9.00$ AM & $93(58.1)$ \\
Use of full-body clothing & $67(41.9)$ \\
Yes & \\
No & $66(41.3)$ \\
Use of protection against the sun & \\
Yes & $94(58.7)$ \\
No &
\end{tabular}

education, the majority of the subjects, i.e. 53 respondents (33.8\%), had finished primary school. Most of the respondents, totalling 122 subjects (76.2\%), were unemployed. The largest ethnic group in this study were the Javanese with 82 subjects $(51.3 \%)$. Mean $25(\mathrm{OH}) \mathrm{D}$ concentration of the subjects was $14.4 \pm 6.4 \mathrm{ng} / \mathrm{mL}$, and 110 $(68.8 \%)$ of subjects had a concentration of $<20$ ng/mL. Mean MMP-9 concentration was 789.8 $\pm 414.7 \mathrm{ng} / \mathrm{mL}$ (Table 1 ).

In Table 2 may be seen the subject activities associated with exposure to sunlight. The majority of subjects $(141$ subjects $=89.1 \%)$ stated that they were exposed to sunlight in the morning. The most common sunbathing period was $>15$ minutes in 72 subjects $(51.1 \%)$. The most common sunbathing frequency per week was $<3$ times/ week in 72 subjects (51.1\%). The most frequent sunbathing hour was before 9:00 AM (90.7\%). There were 93 subjects $(58.1 \%)$ who used fullbody clothing and 94 subjects $(58.7 \%)$ who did not use proctective measures against the sun.

The MMP-9 level was significantly higher in male subjects with a $25(\mathrm{OH}) \mathrm{D}$ concentration of $<20 \mathrm{ng} / \mathrm{mL}$ ( $\mathrm{p}=0.011$ ). In female subjects, BMI was significantly higher in study subjects with 
Table 3. Factor affecting vitamin D concentration in male and female

\begin{tabular}{|c|c|c|c|c|c|c|}
\hline \multirow[b]{2}{*}{ Facbrs } & \multicolumn{3}{|c|}{$25(\mathrm{OH}) \mathrm{D}$ in male } & \multicolumn{3}{|c|}{$25(\mathrm{OH}) \mathrm{D}$ in female } \\
\hline & $\begin{array}{c}<20 \mathrm{ng} / \mathrm{mL} \\
(\mathrm{n}=\mathbf{3 0})\end{array}$ & $\begin{array}{c}>20 \mathrm{ng} / \mathrm{mL} \\
(\mathrm{F}=24)\end{array}$ & $\mathbf{p}$ & $\begin{array}{c}<20 \mathrm{ng} / \mathrm{mL} \\
(\mathrm{n}=\mathbf{8 0})\end{array}$ & $\begin{array}{c}>20 \mathrm{ng} / \mathrm{mL} \\
(\mathrm{HF}=26)\end{array}$ & $\mathbf{p}$ \\
\hline Ag (years) & $59.5 \pm 35$ & $60.2 \pm 27$ & 0.447 & $99.1 \pm 3.0$ & $600 \pm 2.7$ & 0.343 \\
\hline $\mathrm{BM}\left(\mathrm{kg}^{\prime} \mathrm{m}^{2}\right)$ & $23.9 \pm 36$ & $22.8 \pm 42$ & 0.274 & $267 \pm 4.3$ & $24.3 \pm 2.8$ & $0.034^{*}$ \\
\hline Wrist circumfer ence & $86.7 \pm 11.0$ & $80.9 \pm 12.7$ & 0.087 & $91.5 \pm 10.9$ & $85.4 \pm 7.5$ & $0.045^{*}$ \\
\hline MMP-9 (ngmL) & $909.0 \pm 455.6$ & $621.9 \pm 338.7$ & $0.011 *$ & $780.3 \pm 414.4$ & $724.6 \pm 312.6$ & 0.809 \\
\hline Vitamin D intake (mg day) & $6.5 \pm 2.3$ & $6.7 \pm 2.0$ & 0.916 & $6.6 \pm 25$ & $7.1 \pm 2.7$ & 0.855 \\
\hline \multicolumn{7}{|l|}{ Fhyeicd activities** } \\
\hline Regilar & 10 & 11 & 0.491 & 26 & 12 & 0.284 \\
\hline Notregular & 20 & 13 & & 54 & 14 & \\
\hline \multicolumn{7}{|l|}{ Sunbathing time (minutes) } \\
\hline$<15(\mathrm{n}=69)$ & 18 & 11 & 0.199 & 28 & 12 & 0.518 \\
\hline$\geq 15(\mathrm{r}=72)$ & 10 & 7 & & 41 & 14 & \\
\hline \multicolumn{7}{|l|}{ Surbathing frecuency /wreek ** } \\
\hline$<3$ times $(\mathrm{n}=72)$ & 12 & 8 & 0.478 & 46 & 6 & 0.161 \\
\hline$\geq 3$ times $(\mathrm{r}=69)$ & 18 & 15 & & 20 & 7 & \\
\hline \multicolumn{7}{|l|}{ Surbathing hous s*k } \\
\hline$<9.00(\mathrm{n}=128)$ & 28 & 18 & 0.528 & 68 & 14 & 0.373 \\
\hline $2900(\mathrm{n}=13)$ & 2 & 3 & & 5 & 3 & \\
\hline \multicolumn{7}{|l|}{ Use of fill body clothing ** } \\
\hline$Y e(r=93)$ & 20 & 12 & 0.553 & 45 & 16 & 0.440 \\
\hline No $(\mathrm{r}=67)$ & 10 & 12 & & 35 & 10 & \\
\hline \multicolumn{7}{|c|}{ Use of protection against the sun** } \\
\hline $\mathrm{Yes}(\mathrm{n}=60)$ & 16 & 12 & 0.156 & 26 & 12 & 0.534 \\
\hline No $(\mathrm{n}=94)$ & 14 & 12 & & 54 & 14 & \\
\hline
\end{tabular}

$* \mathrm{p}$ value with significance at $\mathrm{p}<0.05$ (independent $\mathrm{t}$ test) $* *($ Chi Square) Mean \pm S.D.

$25(\mathrm{OH}) \mathrm{D}<20 \mathrm{ng} / \mathrm{mL} \quad(\mathrm{p}=0.034)$. Waist circumference was higher in females with $25(\mathrm{OH}) \mathrm{D}<20 \mathrm{ng} / \mathrm{mL}(\mathrm{p}=0.045)$ (Table 3$)$.

\section{DISCUSSION}

The results of this study showed that the mean concentration of $25(\mathrm{OH}) \mathrm{D}$ was $14.4 \pm 6.4$ $\mathrm{ng} / \mathrm{mL}$. This value represents the concentration of vitamin $\mathrm{D}$ below $20 \mathrm{ng} / \mathrm{mL}$, indicating vitamin $\mathrm{D}$ deficiency. The majority of study subjects (110 or $68.8 \%$ ) had $25(\mathrm{OH}) \mathrm{D}$ concentrations of $\leq 20$ $\mathrm{ng} / \mathrm{mL}$ or vitamin $\mathrm{D}$ deficiency, whereas 50 subjects $(31.2 \%)$ had $25(\mathrm{OH}) \mathrm{D}$ concentrations of $>20 \mathrm{ng} / \mathrm{mL}$. To date there is no consensus about the optimal $25(\mathrm{OH}) \mathrm{D}$ concentration, but many experts define $25(\mathrm{OH}) \mathrm{D}$ deficiency as a $25(\mathrm{OH}) \mathrm{D}$ concentration of $<20 \mathrm{ng} / \mathrm{mL}$. A $25(\mathrm{OH}) \mathrm{D}$ concentration in the range of $21-29 \mathrm{ng} / \mathrm{mL}$ is considered to indicate 25(OH)D insufficiency, while a $25(\mathrm{OH}) \mathrm{D}$ concentration of $>30 \mathrm{ng} / \mathrm{mL}$ is termed a sufficient or normal concentration. ${ }^{(5,18,19)}$
The results of this study differ considerably from those of the study by Setiati ${ }^{(20)}$ conducted in Jakarta and Bekasi on 74 elderly females. The latter study showed a lower prevalence of vitamin D deficiency of only $35.1 \%$, wereas in our study vitamin D deficiency was found in $82.8 \%$ subjects. The difference between these results may have been due to the different 25(OH)D assessment methods used. Our study used direct competitive chemiluminescence immunoassay (CLIA) whereas Setiati's study used ELISA. In addition, it has been only since the year 2009 that a standard calibrator for $25(\mathrm{OH}) \mathrm{D}$ measurement became available, such that the variability of measurements has decreased, from >30\% in 1995 to $15 \%$ in $2011 .^{(13,14)}$ The $25(\mathrm{OH}) \mathrm{D}$ is a difficult analyte to measure, since it is a hydrophobic molecule with several molecular forms and is strongly bound to vitamin D-binding protein (VDBP) and since there are no standardized reference materials and measurement procedures for $25(\mathrm{OH}) \mathrm{D}$ assessment. ${ }^{(18,21,22)}$ 
The study of Green et al. ${ }^{(23)}$ showed a prevalence of $63 \%$ for vitamin D deficiency in 18-40 year old females in Jakarta. Goswami et al. ${ }^{(24)}$ reported a prevalence of up to $90 \%$ for hypovitaminosis D in India. These values are somewhat similar to those of our study. Hypovitaminosis D in India is widely found in all age groups, including toddlers, children of schoolgoing age, pregnant women, and adult males and females in urban as well as in rural areas. This is caused by the skin type of Asian Indians, lack of exposure to sunlight, vegetarian habits, and absence of a vitamin D fortification program, although India belongs to countries with a hot climate and abundant sunshine. ${ }^{(24)}$ In the present study, the high prevalence of $25(\mathrm{OH}) \mathrm{D}$ deficiency may have been due to the fact that on average the subjects took sunbaths for $<15$ minutes in the morning only, with $58.1 \%$ using full-body clothing and $41.3 \%$ using protective measures against the sun (sun blocking agents and umbrellas). Sunlight in the morning contains more ultraviolet A (UV-A) than ultraviolet B (UV-B) such that only small amounts of vitamin $D$ are produced by the skin. The best time for UV-B irradiation is between 10.00 to 15.00 . The use of full-body clothing and headscarfs also decreases the skin vitamin D producing capacity. ${ }^{(5,19)}$ In addition, on average the subjects of this study, as do the majority of Indonesians, seldom consume vitamin D containing foods, such as cow's milk, butter, shrimps, salmon and sardines, all of which are not widely consumed by Indonesian communities. ${ }^{(5)}$ The price of vitamin D-containing foods tend also to be high, such that Indonesians have difficulties in obtaining dietary sources of vitamin D.

Vitamin D in the circulation is found in two major forms, i.e. $25(\mathrm{OH}) \mathrm{D}$, which is biologically inert, and $1,25(\mathrm{OH})_{2} \mathrm{D}$, which is the biologically active form. In this study the concentrations of $25(\mathrm{OH}) \mathrm{D}$ were determined because $25(\mathrm{OH}) \mathrm{D}$ is the most abundant form of vitamin $\mathrm{D}$ in the circulation and $25(\mathrm{OH}) \mathrm{D}$ concentration is the best indicator of vitamin D status in the body. ${ }^{(18,25)}$ The half life of $25(\mathrm{OH}) \mathrm{D}$ is $2-3$ weeks, longer than that of $1,25(\mathrm{OH})_{2} \mathrm{D}$, which has a half life of 4 hours only. The active form of vitamin $\mathrm{D}$, i.e. $1,25(\mathrm{OH})_{2} \mathrm{D}$, is not a good indicator for representing the vitamin $\mathrm{D}$ reserves in the body, because its concentrations are influenced by calcium concentrations and particularly decrease in cases of vitamin D deficiency, and more accurately reflect abnormalities of renal function. ${ }^{(25)}$ In vitamin D deficiency the levels of parathyroid hormones are increased, subsequently inducing increased activity of 1á-hydroxylase, such that the concentration of $1,25(\mathrm{OH})_{2} \mathrm{D}$ becomes normal or is increased. In addition, its concentration is very low in the blood, being 1001000 fold lower than that of $25(\mathrm{OH}) \mathrm{D}$, such that it is difficult to detect. ${ }^{25,26)}$

The factors influencing $25(\mathrm{OH}) \mathrm{D}$ concentrations were BMI and waist circumference in females, while MMP-9 concentration was a factor affecting $25(\mathrm{OH}) \mathrm{D}$ concentrations only in male subjects (Table 3). With regard to BMI it may be seen that 83 subjects $(51.9 \%)$ had BMI values of more than $25 \mathrm{~kg} / \mathrm{m}^{2}$, which indicates obesity. In this study it was found that in female subjects the $25(\mathrm{OH}) \mathrm{D}$ concentration was significantly lower in subjects with higher BMI, but not in male subjects. Vitamin D is a fat-soluble vitamin such that with increasing body fat more vitamin $D$ is stored, thus reducing the circulating vitamin D levels. Deposition of excess fat in the body depends on the location of the body fat, which may have an adverse influence on vitamin D status. Obesity is more prevalent in women than in men. Adipose tissue acts as a metabolic well for vitamin $\mathrm{D}$, therefore obesity may decrease the bioavailability of vitamin D. ${ }^{(27-29)}$ Obesity is associated with increased risk of vitamin D deficiency. The inverse association between obesity and serum vitamin D concentration may have been caused by vitamin D deposition in the body fat compartment, by decreased release of vitamin $\mathrm{D}$ into the systemic circulation and by low sunlight exposure. Increases in the number of subcutaneous and visceral adipocytes is associated with decreased vitamin D concentration. ${ }^{(27,29)}$ The study conducted by 
Salekzamani et al. ${ }^{(28)}$ suggested an inverse association of vitamin D status with insulin resistance, the metabolic syndrome, and type 2 diabetes mellitus. Serum levels of $25(\mathrm{OH}) \mathrm{D}$ are the best indicators to determine overall vitamin $\mathrm{D}$ status, since $25(\mathrm{OH}) \mathrm{D}$ is the most abundant form of vitamin $\mathrm{D}$ found in the human body and its concentrations are 1000-fold higher than those of 1,25 dihydroxy-vitamin $\mathrm{D}\left[1,25(\mathrm{OH})_{2} \mathrm{D}\right]$. The circulation of $25(\mathrm{OH}) \mathrm{D}$ is inversely associated with abdominal obesity, hypertriglyceridemia and hyperglycemia. ${ }^{(28)}$

MMP-9 belongs to a family of zincdependent proteases and has extracellular endopeptidase activity. The substrates for MMP9 are the extracellular matrix proteins and adhesion proteins. MMP-9 is important in the extracellular remodeling process and is the principal effector molecule of inflammatory cells. It also plays a key role in vascular diseases, including hypertension, and in the formation of aneurysms. In the present study the mean MMP9 concentration was $789.8 \pm 414.7 \mathrm{ng} / \mathrm{mL}$ (Table1). The study by Welsh et al. ${ }^{(30)}$ on patients with coronary heart disease showed a mean MMP9 concentration of $741.3 \pm 274.7 \mathrm{ng} / \mathrm{mL}$, whereas that of controls was $691.8 \pm 245.0 \mathrm{ng} / \mathrm{mL}$. The mean MMP-9 concentration in the controls of Welsh's study ${ }^{(30)}$ was almost identical with the mean of $659.2 \pm 262.9 \mathrm{ng} / \mathrm{mL}$ found in the present study among subjects with normal vitamin D concentrations (data not shown). On the other hand, in male subjects with $25(\mathrm{OH}) \mathrm{D}$ concentrations of $<20 \mathrm{ng} / \mathrm{mL}$, mean MMP-9 concentration was $909.0+455.6 \mathrm{ng} / \mathrm{mL}$ and in subjects with $25(\mathrm{OH})$ D concentration of $>20 \mathrm{ng} /$ $\mathrm{ml}$ the mean MMP-9 concentration was $621.9+$ $338.7 \mathrm{ng} / \mathrm{mL}$ (Table 3 ). There was a significantly higher mean MMP-9 concentration in male subjects having deficient $25(\mathrm{OH}) \mathrm{D}$ concentrations in comparison with subjects having insufficient and normal vitamin D concentrations, although this difference was not found in female subjects. This statistically non-significant result in females may have been caused by the higher BMI in female subjects as compared with male subjests.
MMP-9 is frequently associated with a susceptibility to vascular plaque rupture. The study of Wasse et al. ${ }^{(13)}$ reported the finding of a significant inverse correlation between $25(\mathrm{OH}) \mathrm{D}$ concentration and MMP-9 concentrations ( $\mathrm{r}=-$ $0.29 ; \mathrm{p}=0.004)$ in patients with terminal renal failure. In the study of Wasse et al. ${ }^{(13)}$ the mean MMP-9 concentration in all patients was $975.2 \pm$ $662.9 \mathrm{ng} / \mathrm{mL}$. The mean MMP-9 concentration in subjects with $25(\mathrm{OH}) \mathrm{D}$ concentrations of $<15 \mathrm{ng} /$ $\mathrm{mL}$ was higher, namely $1155.7 \pm 666.3 \mathrm{ng} / \mathrm{mL}$, and in subjects with 25(OH)D concentrations of $\geq 15 \mathrm{ng} / \mathrm{mL}$ were lower, i.e. $839.8 \pm 593.9 \mathrm{ng} / \mathrm{mL}$ with $\mathrm{p}=0.01$. In Wasse's study ${ }^{(13)}$ the subjects involved were subjects with terminal renal failure, whereas in our study the subjects were persons in normal health. Although the results of Wasse's study showed a correlation, the correlation was low, being below 0.4. In contrast, the study of Lucey et al. ${ }^{(17)}$ which was a randomized double blind placebo controlled trial, showed no effects of vitamin D supplementation on MMP-9 concentrations.

The factor with the strongest influence on $25(\mathrm{OH}) \mathrm{D}$ concentrations was time of contact with sunlight, but in our study this factor did not show any significant influence both in male and female subjects, which agrees with the pathophysiology of vitamin D synthesis. In this study most of the male and female subjects had a sunbathing frequency of $<3$ times/week and their sunbathing time was before 9:00 AM. The main source of vitamin $\mathrm{D}$ is its synthesis in the skin, which is affected by exposure to UV-B radiation, initiating vitamin $D$ synthesis with the formation of double bonds in the $\mathrm{B}$ ring, leading to opening of the $\mathrm{B}$ ring and the formation of previtamin $\mathrm{D}$ that is no longer rigid. ${ }^{(19,31)}$ Ultraviolet irradiation of the skin is measured as the minimal erythema dose (MED) or the total amount of UV irradiation causing minimal erythema of the skin. Exposure to 1 MED is estimated to release 10.000 to $20.000 \mathrm{IU}$ vitamin D into the circulation for 24 hours. ${ }^{(32)}$ Exposure of $40 \%$ of the body surface to $1 / 4$ MED results in the formation of $100 \mathrm{IU}$ vitamin $\mathrm{D}$ per day. These 
values are minimum values of vitamin $D$ synthesis required by the body. Time of exposure to sunlight in the US to obtain 1 MED at midday in the summer is 4-10 minutes for light-skinned individuals and 60-80 minutes for dark-skinned individuals. ${ }^{(32)}$ Vitamin D intake in this study was not associated with $25(\mathrm{OH})$ concentration, both in male and female subjects. Our study subjects were in the low vitamin D intake category, as compared with the recommended vitamin $\mathrm{D}$ intake. In Indonesia vitamin D-containing foods are seldom consumed, because those foods are more expensive.

One of the limitations of this study was the cross-sectional study design. In addition, it is necessary to conduct an experimental study on subjects receiving vitamin D supplementation. The clinical implication of this study is that the community and health personnel in areas of with high sunshine levels such as Indonesia should be alert to the necessity of sunlight exposure as a source of vitamin $\mathrm{D}$, since this study found $25(\mathrm{OH}) \mathrm{D}$ deficiency in the majority of respondents.

\section{CONCLUSION}

A deficiency of $25(\mathrm{OH}) \mathrm{D}$ was found in the majority $(68.8 \%)$ of the subjects. The MMP-9 concentration was increased among male subjects with low $25(\mathrm{OH}) \mathrm{D}$ concentration.

\section{CONFLICT OF INTEREST}

We hereby assure that the manuscript a) is an original work, b) has not been previously published in whole or in part, and c) is not under consideration for publication elsewhere. All authors have disclosed any actual or potential competing interests regarding the submitted article and the nature of those interests. All authors a) have read the manuscript, b) agree that the manuscript is ready for submission to the journal, and c) accept responsibility for the manuscript's contents.

\section{ACKNOWLEDGEMENTS}

We thank the participants in this study for their cooperation. This study was supported by the Faculty of Medicine, Trisakti University, Jakarta, Indonesia.

\section{REFERENCES}

1. $\mathrm{Ku} \mathrm{YC,} \mathrm{Liu} \mathrm{ME,} \mathrm{Ku} \mathrm{CS,} \mathrm{et} \mathrm{al.} \mathrm{Relationship}$ between vitamin D deficiency and cardiovascular disease. World J Cardiol 2013;26:337-46.

2. Alyami A, Soares MJ, Sherriff JZ, et al. Vitamin $\mathrm{D} \&$ endothelial function. Indian $\mathrm{J}$ Med Res 2014;140:483-90.

3. Norman PE, Powell JT. Vitamin D and cardiovascular disease. Circ Res 2014;114:37993.

4. Mozos I, Marginean O. Links between vitamin D deficiency and cardiovascular diseases. Biomed Res Int 2015;109275. DOI:10.1155/ 2015/109275.

5. Holick M. Vitamin D deficiency. N Eng J Med 2007;357:266-81.

6. Anderson JL, May HT, Horne BD, et al. Relation of vitamin D deficiency to cardiovasvular risk factors, disease status, and incident events in a general healthcare population. Am J Cardiol 2010;106:963-8.

7. Wang TJ, Pencina MJ, Booth SL, et al. Vitamin D deficiency and risk of cardiovascular disease. Circulation 2008;117:503-11.

8. Upadhyay RK. Emerging risk biomarkers in cardiovascular diseases and disorders. J Lipids 2015. article ID 971453. DOI: $10.1155 / 2015 /$ 971453.

9. Teixeira BC, Lopez AL, Macedo RCO, et al. Inflammatory markers, endothelial function and cardiovascular risk. Vasc Bras 2014;13:108-15. DOI: $10.1590 / \mathrm{vb} .2014054$.

10. Yabluchanskiy A, Ma Y, Iyer RP, et al. Matrix metalloproteinase-9: many shades of function in cardiovascular disease. Physiology 2013;28:391403.

11. Garvin P, Nilsson L, Carstensen J, et al. Circulating matrix metalloproteinase is associated with cardiovascular risk factors in a middle aged normal population. PloS ONE 2008;3:e1774. DOI: 10.137/journal.pone. 0001774.

12. Jablonski KL, Chonchol M, Pierce GL, et al. 25-Hydroxyvitamin D deficiency is associated with inflammation-linked vascular endothelial 
dysfunction in middle aged and older adults. Hypertension 2011;57:63-9.

13. Wasse H, Cardarelli F, de Staercke C, et al. 25hydroxyvitamin $\mathrm{D}$ concentration is inversely associated with serum MMP-9 in a cross sectional study of African American ESRD patients. BMC Nephrol 2011;12:24. doi: 14712369/12/24.

14. Timms PM, Mannan N, Hitman GA, et al. Circulating MMP-9, vitamin D and variation in the TIMP-1 response with VDR genotype: mechanisms for inflammatory damage in chronic disorders? Q J Med 2002;95:787-96.

15. Shab-Bidar S, Neyestani TR, Djazayery A, et al. Regular consumption of vitamin D fortified yogurt drink (doogh) improved endothelial biomarkers in subjects with type 2 diabetes: a randomized double blind clinical trial. BMC Medicine 2011;9:125. doi: 1741-7015/9/125.

16. Baker A, Wood CL, Timms PM, et al. Changes in vitamin D and matrix metalloproteinase-9 in submariners during a submerged patrols. Occup Environ Med 2014;71:104-8. doi:10.1138/ oemed-2013-101793.

17. Collins A. Practice implications for preventing population vulnerability related to vitamin D status. J Am Ass Nurse Prac 2013;25:109-18.

18. Wielders JPM, Carter GF, Ebert H, et al. Automated competitive protein binding assay for total $25(\mathrm{OH})$ vitamin $\mathrm{D}$, multicenter evaluation and practical performance. J Clin Lab Anal 2014;00:1-14. DOI 10.1002/jcla.21793.

19. McGreevy C, Williams D. New insights about vitamin D and cardiovascular disease: a narrative review. Ann Intern Med 2011;155:820-6. DOI: 10.7326/0003-4819-155-12-20112202-00004.

20. Setiati S. Vitamin D status among Indonesian elderly women living in institutionalized care units. Acta Med Indones 2008;40:78-83.

21. Carter GD. 25-Hydroxyvitamin D: a difficult analyte. Clin Chem 2012;58:486-8.

22. Holmes EW, Garbincius J, McKenna KM. Analytical variability among methods for the measurement of 25 hydroxyvitamin D. Am J Clin Pathol 2013;40:550-60.
23. Green TJ, Skeaff CM, Rockell JEP, et al. Vitamin $\mathrm{D}$ status and its association with parathyroid hormone concentrations in women of child bearing age living in Jakarta and Kuala Lumpur. Eur J Clin Nutr 2008;62:373-8.

24. Goswami R,Ishra SK, Kochupillai N. Prevalence \& potential significance of vitamin D deficiency in Asian Indians. Indian J Med Res 2008;127: 229-38.

25. Fraser WD, Milan AM. Vitamin D assays: Past and present debates, difficulties and developments. Calcif Tissue Int 2013. doi: 10.1007/s00223-012-9693-3.

26. Khan KA, Akram PJ, Fazal M. Hormonal actions of vitamin $\mathrm{D}$ and its role beyond just being a vitamin: a review article. Int J Med Sci 2011;3: 65-72.

27. Johnson LK, Hofso D, Aasheim ET, et al. Impact of gender on vitamin D deficiency in morbidity obese patients : a cross sectional study. Eur J Clin Nutr 2012;66:83-90.

28. SalekzamaniS, Neyestani TR, Alavi-Majd H, et al. Is vitamin D status a determining factor for metabolic syndrome? A case control study. Diabetes Metab Syndr Obes 2011;4:205-12.

29. Cheng S, Massaro JM, Fox CS, et al. Adipocytes, cardiometabolic risk, and vitamin D status: The Framingham heart study. Diabetes 2010;59:2428.

30. Welsh P, Whincup PH, Papacosta O, et al. Serum matrix metalloproteinase- 9 and coronary artery disease: a prospective study in middle aged men. QJM 2008;101:785-91.

31. Lucey A, Hill T, Muldowney S, et al. No effect of vitamin $\mathrm{D}$ supplementation on circulating concentration of matrix metalloproteinase-9 (MMP-9) and tissue inhibitor of metalloproteinase-1 (TIMP-1) in adults aged 2040 and 64 years. Proceed Nutr Soc 2009;68: E151. Doi: 10.1017/S0029665109991078.

32. Holick MF. Sunlight and vitamin D for bone health and prevention autoimmune disease, cancers and cardiovascular disease. Am J Clin Nutr 2004;80:1678S-88S. 